\title{
The State of Competitiveness of Russia on the World Food Market
}

\author{
Saubanov K.R. \\ Bagautdinova N.G. \\ Maklakova N.V.
}

Kazan Federal University, Institute of Management, Economics and Finance, Kazan, 420008, Russia Kazan Federal University, Institute of Language, 420008, Kazan, Russia

\section{Doi:10.5901/mjss.2014.v5n28p36}

\section{Abstract}

The article analyses the modern state of Russia's competitiveness on the world market of agricultural products, the competitiveness of the Russian Federation concerning certain types of food products, identifies problems of the current competitiveness of Russia and the suggested solutions.

Keywords: Ranking of competitiveness, agricultural production, operational performance , productivity, Russia

\section{Introduction}

Located at $11,5 \%$ (1/9) of the total area of the Earth, Russia produces only 2,8\% (2005 [1]) of all food supplies of the world. For comparison, China - 18,5\%, India and the USA - 10\%, Brazil - 9\% [1]. Thus, the agricultural potential of our country is huge, but until now it is not implemented even for a third yet.

\section{Result}

The aim of this study is the search for possible ways to develop the agricultural potential of Russia in the global economy. Assessment of current situation of the country on world food market was carried out in order to reach the designated goal.

Most of food supplies the produced in our country goes to the domestic market, but some part is sold abroad (Table 1).

Table 1: Main food commodities exported from Russia to the world market in 2007

\begin{tabular}{|c|l|c|c|c|c|}
\hline № & Item & Thousand dollars & Thousand tons & Average export value of 1 ton, dol. & Share in world export, \% \\
\hline 1 & Wheat & 3608763 & 14444,1 & 250 & 10,9 \\
\hline 2 & Oil & 466541 & 613,7 & 760 & 13,0 \\
\hline 3 & Barley & 416483 & 1872,8 & 222 & 7,9 \\
\hline 4 & Confectionery & 162646 & 87,1 & 1868 & 1,6 \\
\hline 5 & Beer & 149705 & 309,1 & 484 & 2,6 \\
\hline 6 & Refined sugar & 123276 & 301,1 & 409 & 1,3 \\
\hline 7 & Wheat flour & 94294 & 277,6 & 340 & 2,6 \\
\hline 8 & Tea & 60188 & 10,3 & 5845 & 0,6 \\
\hline
\end{tabular}

Source: made and calculated according to the Food and Agricultural Organization of the United Nations (FAO) [1]

From the above table we can see that wheat is the basis of agricultural exports of the Russian Federation. At that, Russia's share on the global wheat market reached almost 11\% in 2007.

Producers of the USA (24,8\% of the world wheat market in 2007), Canada (13,2\%), Australia (11\%), France $(10,8 \%)$, Argentina (7,3\%), Kazakhstan (4,6\%) and Germany (3,5\%) are potential competitors of Russian wheat on foreign markets [1].

If we compare the domestic prices of agricultural producers in Russia and these countries, the Russian wheat is 
very attractive. Thus, in 2007 the domestic price of producers of Russian wheat was $\$ 182$ per ton, which is significantly lower than in Argentina (334 USD), France (US \$ 266,7), Germany (USD 245,3), United States (US \$ 238); it yields only to Kazakhstan (USD 136,9) [1].

Thus, at the moment the wheat produced in the Russian Federation, is quite competitive on the world market and, perhaps, the most competitive domestic agricultural product.

Sunflower oil, barley, refined sugar, beer and confectionery, made in Russia, are also competitive in price on world markets. On this basis, we can conclude that almost all food that is exported by our country is competitive to some extent. But then the question arises: what about food products that are not exported to the foreign market?

If crop production of the domestic agricultural complex is rather competitive on the world market, the situation with animal products is precisely the opposite one.

For example, if to compare the price of chicken meat in Russia and in the leading countries-exporters of this product, the outcome of the competition is obvious (not in favor of our country): in Russia a ton of produced chicken is USD 2 210,7, in Holland - USD 1284,6., in the United States - USD 1316,4, in Brazil - USD 1384, in Belgium - USD 1633,1 , in Germany - USD 1649,4 [1].

The situation is similar in pork production. If in 2007 the price of a ton of this meat in 2007 in Russia was USD 3087,2, in the leading countries-exporters of pork - 40-50\% lower (in the United States - USD 1446,5 , in Spain - USD 1448,1, in France - USD 1621, in Denmark - USD 1698,1, in Belgium - USD 1732,6$)$ [1].

From the above we can make a conclusion that in this situation the Russian animal products are not able to compete in foreign markets. However, there are several important (in terms of nutrition) products which, in our opinion, can really compete with foreign counterparts in the long-term perspective.

It is, above all, about the cow's milk. In 2007 the share of Russia in world production of cow's milk was $5.6 \%$, but its export was only $0.2 \%$ of world export of cow's milk that year (Table 2 ).

Table 2: Performance indicators of the key exporters of cow's milk in 2007

\begin{tabular}{|c|l|c|c|c|c|c|c|}
\hline № & Country & $\begin{array}{c}\text { Export, } \\
\text { Thousand } \\
\text { USD }\end{array}$ & $\begin{array}{c}\text { Export, } \\
\text { Thousand } \\
\text { Tons }\end{array}$ & $\begin{array}{c}\text { Average Export Cost } \\
\text { of 1 ton, USD }\end{array}$ & $\begin{array}{c}\text { Price of Producers, } \\
\text { USD/ton }\end{array}$ & $\begin{array}{c}\text { Share in World } \\
\text { Export, \% }\end{array}$ & $\begin{array}{c}\text { Share in World } \\
\text { Production, \% }\end{array}$ \\
\hline 1 & Germany & 1019885 & 1793,1 & 569 & 457,8 & 26,1 & 5,0 \\
\hline 2 & France & 458625 & 758,9 & 604 & 424,5 & 11,1 & 4,3 \\
\hline 3 & Belgium & 319503 & 570,0 & 561 & 445,0 & 8,3 & 0,5 \\
\hline 4 & Czech Republic & 254623 & 533,6 & 477 & 418,6 & 7,8 & 0,5 \\
\hline 5 & Austria & 237719 & 402,5 & 591 & 463,3 & 5,9 & 0,5 \\
\hline 6 & Holland & 211863 & 400,9 & 528 & 444,1 & 5,8 & 1,9 \\
\hline 7 & Great Britain & 206676 & 429,7 & 481 & 402,3 & 6,3 & 2,4 \\
\hline 8 & Slovenia & 103075 & 208,6 & 494 & 381,4 & 3,0 & 0,1 \\
\hline 9 & Russia & 7981 & 10,3 & 772 & 328,9 & 0,2 & 5,6 \\
\hline 10 & All countries & 3837458 & 6860,1 & 559,4 & 488,1 & 100,0 & 100,0 \\
\hline
\end{tabular}

Source: made and calculated according to the Food and Agricultural Organization of the United Nations (FAO) [1]

Meanwhile, the price of producers of cow's milk in the Russian Federation is significantly more attractive than of the world's largest exporters of this product. Thus, according to the FAO, in 2007 it was USD 328,9 per ton, while in Austria USD 463,3, in Germany - USD 457,8, In Belgium - USD 445, in the Netherlands - USD 444,1, in France - USD 424,5, in the Czech Republic - USD 418,6, in the UK - USD 402,3, in Slovenia - USD 381,4.

Thus, the competitive potential of the Russian milk on the world market is large. However, until in our country its consumption exceeds domestic production (in 2008 - by 6,6\% [2, p. 495, 507]), there will not be any export orientation of domestic producers of milk, and this is logical and reasonable in terms of food security of the country.

As for possible strategic directions of sales of domestic food products, including dairy products, in our opinion, the Japanese market is the most promising in this respect. Thus, annual imports of agricultural products in the country is about $55 \%$ of its domestic production, and it exceeds the exports more than 21 times [1]. Corn, pork, beef, wheat, wine, chicken, cheese and fruit are the basis of Japanese food imports.

Assessment of the share that it occupies in the world exports of food is one of the ways to assess the country's competitiveness on the global food market (Fig. 1).

The USA is the leader in the global food market. For example, in 2005-2007 the share of this country in the world 
export of agricultural products was 10,2\%. Netherlands (7,7\% of world exports) and France (6,9\%) are behind the United States on the second and third places respectively. In 2005-2007 the total market share of 15 leading exporters of food products and agricultural raw materials was $67 \%$.

Russia takes only the $26^{\text {th }}$ place in the world in terms of specific weight in the world exports of food with the average annual market share 0,7\% in 2005-2007. However, according to the index TPI (Trade Performance Index), which is used by the International Trade Centre to assess the competitiveness of some sectors of the economy in the international market, the position of the Russian Federation is even lower. For example, in 2008 by this index Russia was on the $94^{\text {th }}$ (out of 180 countries) and the $60^{\text {th }}$ (out of 162 countries) places in the world, respectively, on the world market of fresh and processed food products [3].

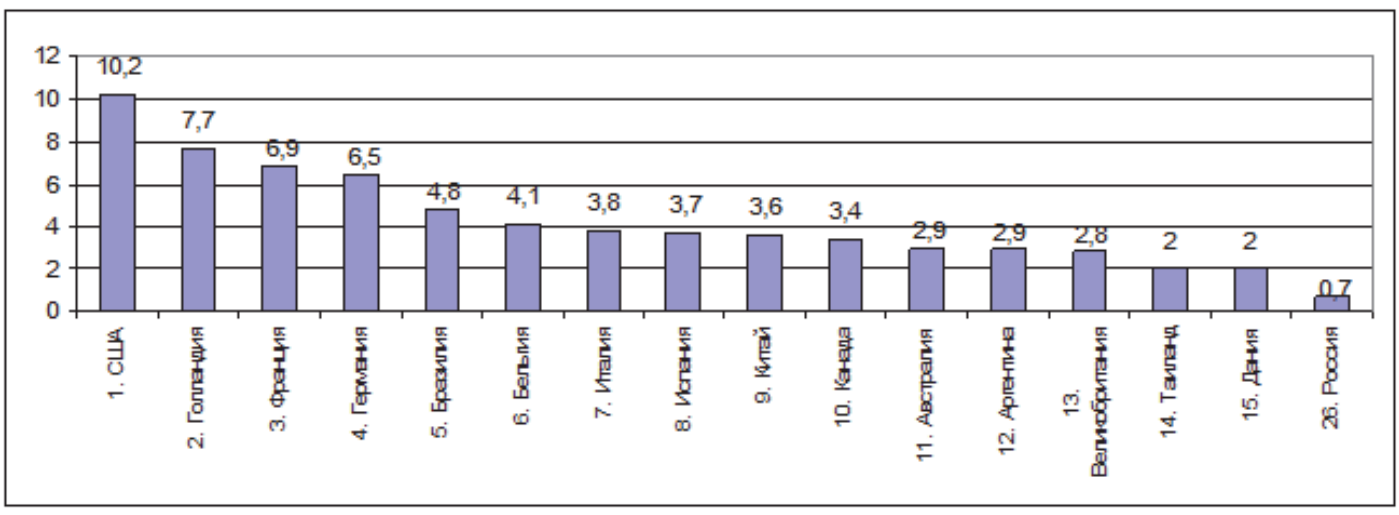

Fig.1. Rating of countries by specific weight in world exports of food products and agricultural raw materials in 2005$2007, \%[1]$

The question arises: what is necessary to do in order to improve the competitiveness of Russia on the global market of agricultural products? First, it is necessary to provide a significant increase of operational productivity in the agricultural sector of the national economy. Competitiveness of the developed countries of the world is greatly determined by high productivity of agriculture (Fig. 2).

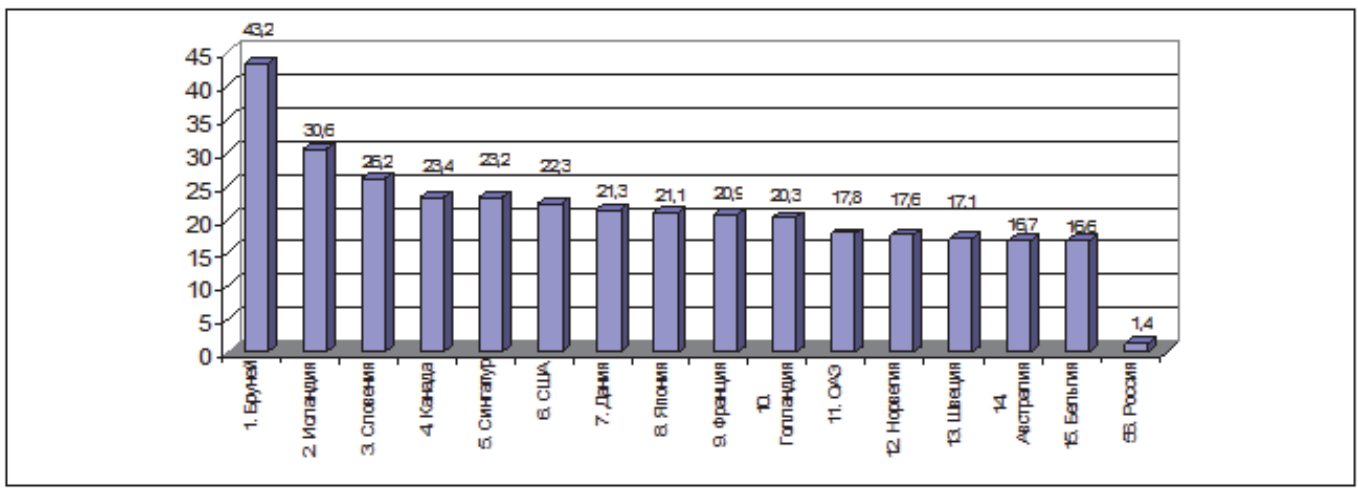

Fig. 2. Rating of countries by operational productivity in agriculture in 2005, thousand USD per 1 worker [1]

As we can see from the figure above, Russia takes the $56^{\text {th }}$ place in the world with the index of USD1400 per 1 worker engaged in agricultural production by operational productivity in agriculture [1]. At that, such countries as Panama (the $55^{\text {th }}$ place), Guyana (the $57^{\text {th }}$ place), Dominican Republic (the $58^{\text {th }}$ place) and Colombia (the $59^{\text {th }}$ place) are close to Russia. 


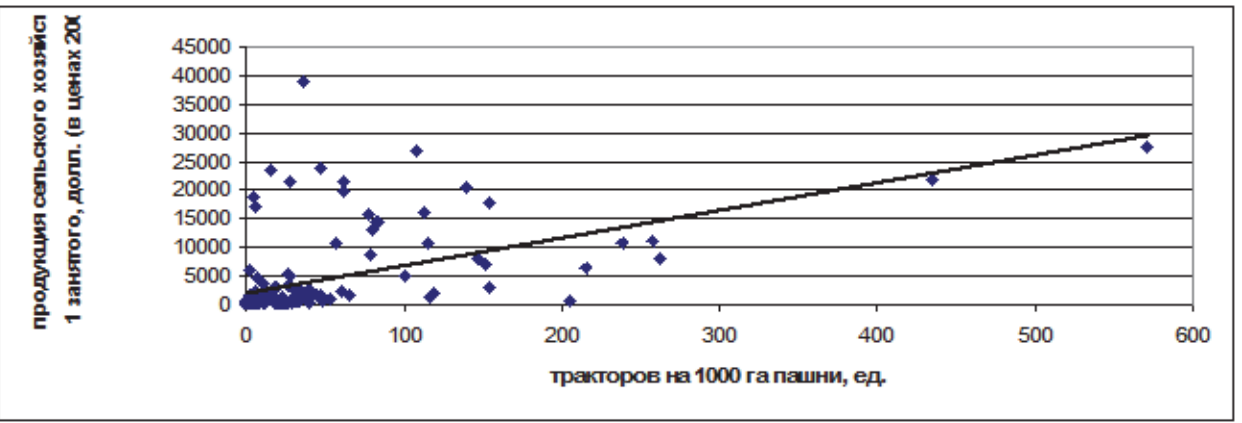

Fig. 3. Influence of mechanization on productivity in 139 countries of the world (data of 2006 [1])

Mechanization of agricultural production is the major factor of productivity increase in agricultural production (Fig. 3). Correlation analysis of influence of provision of agricultural machinery on the performance of the agricultural labor in 139 countries showed that there is a strong direct correlation between them (correlation coefficient - 0,52).

It is necessary to say that by equipment provision of agricultural production by tractors, Russia (in $2006-3,6$ units per 1000 hectares of arable land [1]) is on the same level with such countries as South Africa, Samoa, Oman, Namibia, Peru, and by the number of combined harvesters per 1000 hectares of arable land (in 2006 - 1 unit [1]) - at the same level with Tunisia, Syria, Mexico, Guinea, Egypt, Bosnia and Herzegovina, Algeria.

Of course, such weak mechanization of domestic agriculture negatively affects the competitiveness of Russian agricultural producers not only on the foreign, but also on the domestic market. However, the low level of fertilizer use also makes a significant contribution to the reduction of competitiveness. For example, if in 2006 in China and the United States respectively 25,2 million and 50,4 tons of mineral fertilizers were used, in Russia - only 1,5 million tons [1]. As a result, in 2006 the yielding capacity of cereal and leguminous crops in Russia was 18,9 kilograms per hectare of harvested area, while in the USF and China - 62,9 and 51,7 respectively [4, p. 205-206].

\section{Conclusion}

Thus, first of all it is necessary to provide a significant increase of material-technical facilities of the agricultural sector of the national economy in order to improve the competitiveness of Russia on the global market of agricultural products and to enhance food security of the country. But it will be possible to do by only by a substantial leveling of influence of dealers of agricultural raw materials on the production process in agriculture. And only the state can cope with this task. Only then the agricultural producers will make a profit and move to expanded production, will start to improve the technological processes and to buy new machinery and fertilizers in sufficient quantity, will be able to attract skillful staff and will become competitive on both the foreign and domestic markets. But until the purchase prices in agriculture are 23 times lower than the prices at the national food market, it will not be possible, unfortunately, to talk about the competitive growth of Russian farmers.

\section{References}

Food and Agriculture Organization of the United Nations (FAO) / http://faostat.fao.org

Agropromyishlennyiy kompleks Rossii v 2008 godu. - M.: Ministerstvo selskogo hozyaystva RF, 2009. - $547 \mathrm{~s}$.

International Trade Centre / http://www.intracen.org

Rossiya i stranyi mira. 2008.: Stat.sb. / Rosstat. - M., 2008. - 361 c.

D. Kh. Gallyamova, A.R. Toumashev, V.V. Malaev. Influence of Globalization on Development of the Russian Economy // Mediterranean Journal of Social Science. - Vol.5. - №18. - pp. 133-138.

Zobova I.Yu., Malganova I.G. (2014). Territorial aspects of the institutional transformation of fiscal system // Mediterranean Journal of Social Science. - Vol.5. - №8. - pp. 153-158.

Safiullin Lenar, Fatkhiev Artur, Saipullaev Ullubi, Bagautdinova Nailya. Problems and decision in the field of distance education. Procedia - Social and Behavioral Sciences. Vol. 131, pp. 111-117 // 3rd World conference on educational technology researches Turkey 07-09.11.2013.

Razumovskaya, E.M. , Kutsevol, N., Popov, M., Mishakin, T., Leto, L., Tsalikova, V. The effectiveness of management practice in the market of socially important services. Asian Social Science, Volume 10, 28 September 2014, Pages 118-122

Razumovskaya, E.M.,Lapidus, L.V., Mishakin, T.S., Popov, M.L. Features and peculiarities of the Russian passenger rail market development. Mediterranean Journal of Social Sciences vol. 5 (18 SPEC. ISSUE), pp. 165-170. 